\title{
Parathyroid Hormone-related Protein Measurement
}

National Cancer Institute

\section{Source}

National Cancer Institute. Parathyroid Hormone-related Protein Measurement. NCI

Thesaurus. Code C117851.

The determination of the amount of parathyroid hormone-related protein present in a sample. 